\title{
Application of the Ladder Snake Game Media to Improve the Learning Outcomes of Students in Grade VI-D SDN Tawangsari I Taman
}

\author{
Eny Mulyamti \\ Universitas Negeri Surabaya \\ Surabaya, Indonesia \\ emulyamti@gmail.com
}

\begin{abstract}
This study aims to determine the improvement of student learning outcomes after using the game media snake ladder. The research method used in this research is classroom action research by selecting the design model from Kemmis and Mc model. Taggart from Deakin University, Australia conducted for two cycles. The first cycle obtained by the value of learning achievement reached $74.19 \%$, where the result is $\geq 75$ (KKM) which shows that in the first cycle of the classical students have not finished learning. The second cycle obtained the value of learning completeness reached $87.09 \%$, where the results $\geq 75$ (KKM) which indicates that the second cycle has reached the success indicator.
\end{abstract}

Keywords-Media learning; Kemmis and Mc. Taggart; Learning outcomes

\section{INTRODUCTION}

Education has significance for the progress of a nation. Article 1 Paragraph 1 of Law Number 20 Year 2003 on the National Education System states that education is a conscious and planned effort to create an atmosphere of learning and learning process so that learners actively develop their potential to have spiritual spiritual power, self-control, personality, intelligence, noble character, as well as the necessary skills of himself, society, nation and state.

While the function and general purpose of education in Indonesia as described in Article 3 of Law Number 20 Year 2003 is to develop the ability and form the character and civilization of a dignified nation in order to educate the life of the nation, aims to develop the potential of learners in order to become a human being who believes and cautious to God Almighty, have noble character, healthy, knowledgeable, capable, creative, independent, and become citizen of democratic and responsible.

In a process of the nation's journey to civil society, which is the nation and state society based on and leads to the concepts and values of Pancasila and the 1945 Constitution, civic education as one of the curriculum content of basic education, need to adapt adaptively and coherently with the needs and demands of society which is always changing.

The Civic Mission with its new paradigm is to develop a psycho-pedagogical and socio-andragogical democratic education. The intelligence of democratic citizens that need to be developed is not just spiritual, emotional and social intelligence. According to Suryadi and Soemardi (1999) to reconceptualize civic education with a new paradigm, it can be approached from a system point of view.

One of the systems in the living order of the state, namely the institutional system, which refers to the state institutions and governmental institutions according to the constitution and prevailing laws and regulations. This understanding of state institutions and government institutions is a basic prerequisite for citizens to participate in the life of the state and government.

Learning Pkn should be able to equip students with adequate knowledge and intellectual skills and practical experience in order to have competence and effectiveness in participating. Two things that should be the attention of teachers is the provision of learning materials knowledge and methods that are in line with the demands and expectations of Civics, namely to develop citizens' intelligence in the spiritual, rational, emotional and social dimensions and develop protégés participate as citizens to sustain the growth and development of citizens good country.

At SDN Tawangsari I Taman in the odd year VI-D class of $2016 / 2017$ on daily test result 1 , minimal completeness completeness (KKM) is still below the minimum requirement of $75 \%$, students who reach KKM, from 31 students, there are still 12 which has not completed or completeness only reached $61.29 \%$.

The author's experience, in Civics learning so far, is still conventional, so it has not been able to encourage students to actively participate in learning. Civic learning during this time seems to be less challenging learning, or even seem boring. So it does not improve the achievement of learners in achieving learning outcomes. It is very influential on the results of less than optimal learning.

Oemar Hamalik in Arsyad [1]argued that the use of learning media in teaching and learning roses can generate new desires and interests, generate motivation and stimulation of learning activities, and even bring psychological influences on students 
Based on the above explanation, the researcher will conduct research with the title of Improving Learning Outcomes according to the 1945 Constitution Amendment Result Through Snake Game Media on Grade VI-D Students SDN Tawangsari I Taman year 2016-2017.

In accordance with these problems, this research has a purpose that is: To know the improvement of student learning outcomes after using the game media snake ladder.

According Djamarah[2],the result is the achievement of an activity that has been done, created, both individually and in groups. Results will never be generated as long as people do nothing.

Learning outcomes according to Suratinah Tirtonegoro[3] : assessment of learning activity results expressed in the form of symbols, numbers, letters or sentences that can reflect the results achieved by each student within a certain period.

Based on the opinion of the above figures it can be concluded that the learning outcome is the ability to learn all the knowledge, attitudes and skills acquired and owned by the students after he received experience and treatment provided by the teacher so as to run the knowledge in everyday life.

Citizenship is a subject that focuses on religious, sociocultural, linguistic, age and ethnic formation, to be an intelligent, skilled, and characterized citizen mandated by Pancasila and the 1945 Constitution (Curriculum-Based Competence, 2004). The foundation of Civics is Pancasila and the 1945 Constitution, rooted in religious values, the national culture of Indonesia, responsive to the demands of changing times, and Law no. 20 Year 2003 on National Education System, Competency Based Curriculum in 2004 as well as Special Guidelines for the Development of Syllabus and Assessment of Citizenship Subjects issued by the Ministry of National Education-Directorate General of Primary Secondary Education-Directorate of Secondary Education.

The objectives of the Citizenship course are 1) to think critically, rationally and creatively in dealing with citizenship issues, 2) to participate in a quality and responsible manner, and to act intelligently in the activities of society, nation and state.

The scope of Civics subject includes the following aspects. 1) unity and unity of the nation, including: living in harmony in diversity, love of the environment, pride as the nation of Indonesia, youth oath, the unity of the Unitary State of the Republic of Indonesia, participation in state defense, positive attitude towards the Unitary State of the Republic of Indonesia, Openness and justice guarantee.

According to Briggs (in Rudi Susilana and Cepy Riyana [4] , the media is a tool to provide incentives for students to make the learning process.Myarso in Rudi Susilana and Cepy Riyana (2009: 06) say that the media is everything that can be used to channel the messages that can stimulate the thoughts, feelings, attention and willingness of students to learn. Conclusion of the authors, the learning media serves to improve the quality of PBM. Results of students using the media will last long settled so as to have the quality of learning has a high value.
Understanding the game according to Indonesian General Dictionary (2013: 732) is a play tool that is used early childhood, can be in the form of blocks, puzzles or other objects that are considered can be played. Snake ladder is a board game for kids that is played by 2 or more people. Board games are divided into small boxes and in some boxes drawn a number of "ladders" or "snakes" that connect it to other boxes. The use of a snake ladder game here adapted the needs of the teacher itself. Therefore, the author adjusts this game according to the author's goal, which is a game of knowledge, to spur the child, motivate the child, to be willing and able to repeat the learning materials that have been studied, in order to achieve optimal success, in the absorption of learning materials.

The advantages of a ladder snake game media are as follows, a) a ladder snake game game can be used in $\mathrm{K}$, since activity I is fun so the child is interested to learn while playing. b) enables children to participate directly c) to help all aspects of development, one of which develops the intelligence of mathematical logic d) stimulates the child to learn to solve simple problems, unnoticed by the child e) the ladder snake game can be done outside and inside the classroom. The disadvantages of the ladder snake game media are, a) the use of snake ladder medium takes time to explain to the child b) the landing snake game media does not develop all data subjects c) lack of understanding of rules of the game by the child, may cause riot d) for children who are not mastering the material will be difficulty in the game.

\section{METHOD}

\section{A. Research Design}

The design of this study included in classroom action research (PTK). As for the research design, there are several models of classroom action research offered by experts, but the researchers chose the design model of Kemmis and Mc model. Taggart from Deakin University, Australia (adopted from the Kemmis and Taggart models, in Arikunto[5] . This design model consists of four components, namely: Maintaining the Integrity of the Specifications is:

\section{Picture 1.}

Implementation Chart

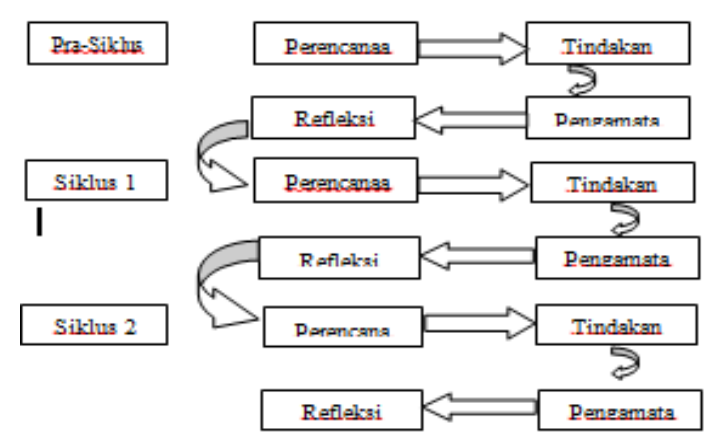

\section{Pre- Cycle}

Early reflection stage. Based on the results of preliminary data analysis of the daily examination Pkn election materials and election, achievement of learning outcomes have not met 
the target class KKM. The data shows from 31 students, only 19 students who get the minimum score according to KKM amounted to 75 . Achievement of learning outcomes at precycle level of $61.29 \%$. so there are 12 students who earn learning outcomes under KKM or equal to $38.71 \%$. So researchers want to improve learning outcomes $\mathrm{Pkn}$, by using the game media snake ladder. Expected student learning outcomes will increase after using the game media snake ladder.

\section{Cycle 1}

The teacher does the planning stages in demonstrating the learning media and then proceeds with the action stage. Furthermore, doing the observation stage in which doing this research researchers work with colleagues as a collaborator, to know the changes in teacher activities and students in the learning process in each cycle. In the last stage in the first cycle is the reflection stage, ie researchers with observers analyzing the results of data collection to see the weaknesses and advantages of the implementation process of learning in cycle 1 which can then be used as a reference to improve the action on cycle 2 .

\section{Expandable 2}

The teacher does the planning stages in demonstrating the learning media and then proceeds with the action stage[6]. Furthermore, the observation stage where researchers also use the method of observation (observation) conducted by collaborators to determine changes in teacher activity and students in the learning process in each cycle. In this phase, the learning activity sheet is provided. This observation sheet was used to obtain data on the effect of learning through discussion with the game media of the ladder snake, on the students of class VI-D. In the last stage of the second cycle is to discuss things gained during the observation of action in cycle 2 . It is expected that in this cycle 2, student learning outcomes show the optimal changes in accordance with the expected learning objectives, so that students' learning completeness in line with expectations. Thus in cycle 2 is expected to show success in the implementation of learning PKN, so that learning declared successful.

he template is used to format your paper and style the text. All margins, column widths, line spaces, and text fonts are prescribed; please do not alter them. You may note peculiarities. For example, the head margin in this template measures proportionately more than is customary. This measurement and others are deliberate, using specifications that anticipate your paper as one part of the entire proceedings, and not as an independent document. Please do not revise any of the current designations.

\section{B. Data Analysis Techniques}

1. Instruments or data collection tools used in learning Civics are:
a) Student activity observation sheet.
b) Observation sheet of teacher activity.
c) Problem evaluation test 1

d) Problem evaluation test 2

\section{Data Collection}

a) Qualitative data in the form of observation / observation data on teacher and student activities during the learning process.

b) Quantitative data in the form of data table value obtained from student re-examination.

3. Data collection techniques

Technique of data collecting done by two way, that is with test and non test.

a) The test data is obtained from students' repeat results.

b) Non test data was obtained from observation instruments.

\section{Data Analysis}

To answer the problem formulation on the above class action research used the analysis of learning process process. Techniques of data analysis in this study are as follows:

a) Analysis of teacher activity observation sheet

Researchers at this stage use data descriptively quantitatively by using the formula:

$$
\mathbf{P}=\frac{\mathbf{F}}{\mathbf{N}} \times 100 \%
$$

Information :

P: Percentage of occurrence frequency occurrence

F: The number of activities performed in the process learning

$\mathrm{N}$ : Total activity count

\begin{tabular}{|c|c|}
\hline$\geq 80 \%$ & Very Good \\
\hline $60 \%-70 \%$ & Good \\
\hline $40 \%-50 \%$ & Enough \\
\hline$<20 \%$ & Less \\
\hline
\end{tabular}

b) Analysis of student observation sheets

$$
M=\frac{\sum f}{N} \times 100 \%
$$

Information :

$\mathrm{M}=$ Percentage of student activity

$\Sigma \mathrm{f}=$ Number of activities implemented in the learning activity

$\mathrm{N}=$ Number of students

\begin{tabular}{|c|c|}
\hline$\geq 80 \%$ & Very Good \\
\hline $60 \%-70 \%$ & Good \\
\hline $40 \%-50 \%$ & Enough \\
\hline$<20 \%$ & Less \\
\hline
\end{tabular}

c) Analysis of student learning outcomes

$$
\mathbf{B}=\frac{\mathbf{F b}}{\mathbf{N}} \times 100 \%
$$


Information :

$\mathrm{B}=$ Percentage of student learning outcomes

$\mathrm{Fb}=$ Number of successful students

$\mathrm{N}=$ Total number of students

\section{DESCRIPTION OF RESEARCH IMPROVEMENT RESEARCH RESULTS}

From the research that has been carried out obtained by observation data in the form of management observation through manipulative method of snake ladder game and post test data write students in each cycle.

\section{A. Pre Cycle}

Actually pre cycles are the steps performed before doing the research action. This study was conducted after looking at daily test results on KD 2.1. From this pre-cycle stage, the researcher got the data obtained from daily test result as follows: The result of pre cultivation stage score from 31 students only $61.29 \%$ that fulfill the learning completeness, that is only 19 students who can get the value that meet KKM 75 , while $48.4 \%$ have not reached the KKM, which is 12 students whose results are below KKM 75. From the results of these observations researchers need to conduct classroom action research to improve the results of learning Civics in students of class VI-D.

\section{B. Cycle 1}

Planning stage -> Implementation Phase -> Observation Stage :

1. Teacher activity data in Learning Activity

Based on the data analysis in cycle 1 , the teacher activity obtained with a total score of $76 \%$ in accordance with the steps listed in the RPP, but still found many deficiencies and weaknesses. This can be seen from the teacher activity that is still lacking and not appearing among the less open to the student response so that there are some learners who do not understand learners. Thus it can be said that the teacher activity during the learning process in cycle 1 is said to still need to be improved again.

2. Student Activity in Groups

The average student activity in the group is $65.05 \%$ percent This indicates that: 1) learners are less able to listen to a brief description of the material submitted. 2) learners are less able to understand the course of the game. 3) students are less able to be able to discuss the results of workmanship LKS with his group 4) learners are less able to work with his friends. 5) learners are less able to do evaluation questions

3. Learning outcomes

Can be explained that by applying the snake ladder game method obtained the value of learning mastery reaches $74.19 \%$ or there are 23 students from the total 31 students, who have completed study. The result shows that in the first cycle the students have not finished their study completely, because the percentage of class completeness that get the value of $\square 75$ (KKM) is only $74.19 \%$ smaller than the desired completeness presentation that is equal to $75 \%$.

\section{Reflection Stage}

This stage is the last stage of a learning process. This activity is a feedback on the implementation of learning. a commonly overlooked feedback issue, but it is really important for the success of a learning process. Without this stage, especially without feedback, the learning process has not run fully. At this stage the author, reflecting what has been done in cycle.

At this stage the authors process the data obtained at the time of observation. Existing data are analyzed. Based on the data in the first cycle obtained the following conclusions:

In the process of learning activities in cycle 1 obtained information from the observation as follows:

1. Teachers are less responsive to students to seek broad information about the material to be taught.

2. Teachers less involving learners to demonstrate instructional Media.

3. Students cannot be conditioned in an orderly manner due to the less ideal group.

4. Learning outcomes on cycle 1 as a whole have started to show improvement although the classical still found activity of learner activity that still less maximal in receiving subject matter.

\section{Stage of Improvement}

After doing the reflection, the steps of the improvements that will be done by the researcher are as follows:

1. Teachers are more motivating learners to be more involved in seeking broader information about the material that has been learned.

\section{Teachers involve more learners to demonstrate props}

3. Teachers should condition the class better for the delivery of learning materials can be accepted by all learners maximally.

\section{E. Cycle 2}

Planning stage -> Implementation Phase -> Observation Stage :

\section{Teacher activity data in Learning Activity}

From observation data of teacher activity on Civic subject through game media of snake ladder can get a total score of $88 \%$, this shows that RPP in cycle 2 has been done well.

\section{Student Activity in Groups}

The activities of learners in the learning through snake ladder game method is very good category. Overall activity learners have met the criteria of the points of value expected. In 
the table above is known that the increase in the activity of learners in cycle 2 has increased to $82.52 \%$ means that the learners' activities have reached the indicator of success. Students can enjoy the game very well.

\section{Learning outcomes}

The use of game media snake ladder, obtained the average value of student achievement is $87.09 \%$ It is in accordance with the wishes of researchers that the action of learning using the game media snake ladder on the subject of Civics in KD State institutions according to the 1945 constitution amendment results declared successful, if the average test result increases, with KKM class $75 \%$. This means that the student evaluation activity has reached the success indicator, so the Class Action Research is not continued in the next cycle or ending in cycle 2 .

\section{Reflection Stage}

Data from observations as follows:

1. During the process of learning activities, the researcher has carried out all the stages of activities listed in the RPP well. Although there are still shortcomings but the percentage of implementation for each aspect is good enough.

2. Based on the results of observation cycle 2 note that the activity of students experience a better improvement during the learning process.

3. Disadvantages and weaknesses in previous cycles have been improved and improved so that learning becomes better.

4. Students' learning outcomes in cycle 2 reached $87.09 \%$, so it has been above the KKM class (indicator of success) 75\%.

5. Results in cycle 2 are considered successful, so the research ends in cycle 2 .

\section{DisCUSSION OF RESEARCH RESUlTS}

\section{A. Teacher activities}

Graph 1.

Comparison of Teacher Activity In Cycle 1 and Cycle 2

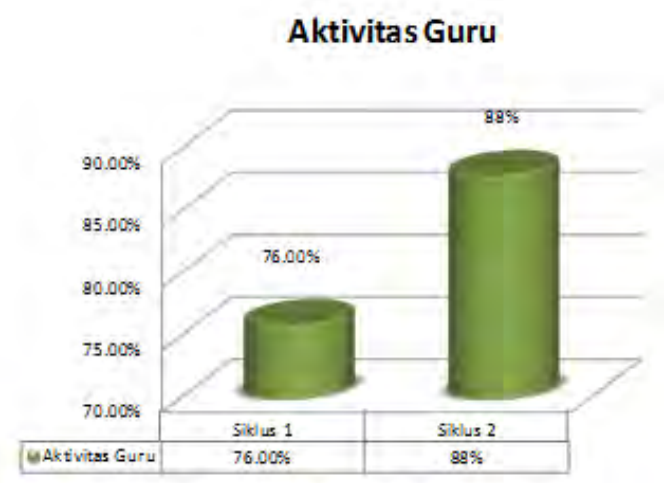

Based on the observation of teacher activity on cycle 1 as a whole has been going well but there are certain activities that still have shortcomings and weaknesses. Percentage achieved in cycle 1 is $76 \%$. The percentage achieved in cycle 2 is $88 \%$.

\section{B. Student activities}

Graph 2.

Student Activity Comparison In Cycle 1 and Cycle 2

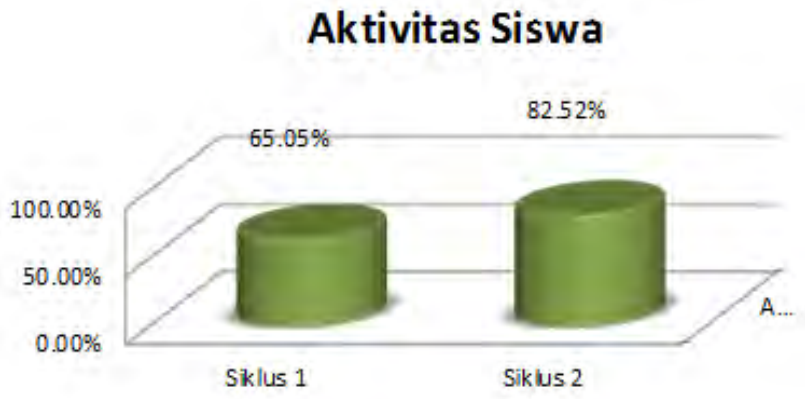

Based on graph 4.2 above, the average of student activity in cycle 1 is $65,05 \%$ and mean of activity of student in cycle 2 is $82,52 \%$. From the above graphs can be seen that the cycle 2 students are more interested in the learning that is delivered through the game media snake ladder. This increase in student activity can also be seen in his enthusiasm in discussions with the game media, actively asking questions, correcting peer answers and working in intergroup competition. as well as in doing evaluation tests well.

\section{Student learning outcomes}

Graph. 3.

Improving Student's Student's Completion At Cycle 1 and Cycle 2

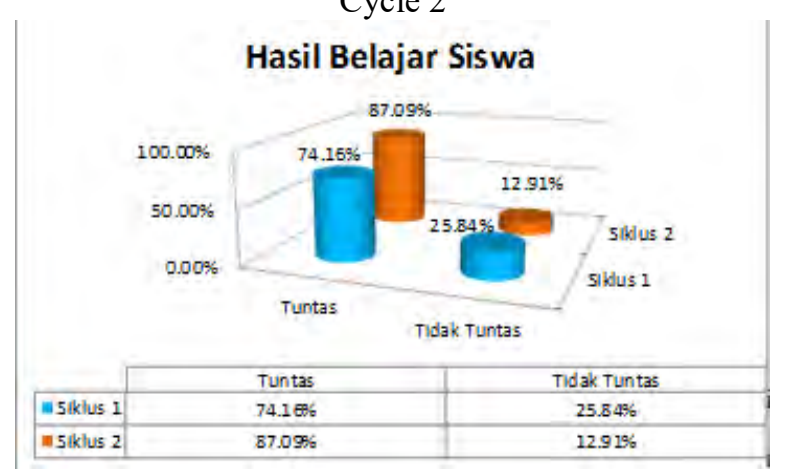

Mastery of student learning has reached the classical above 75 percent, as expected by researchers. In the graph also shows that student learning outcomes can be fulfilled with the increase of student enthusiasm through the game snake ladder media. In cycle 2 so that they are able to absorb and understand learning on the material of State institutions in accordance with the 1945 Constitution of the amendment result. Students also look more enthusiastic in opinion, refute the opinion of friends and more quickly and precisely in doing the test questions given by researchers. Equations

\section{CONCLUSIONS AND SUGGESTIONS}

\section{A. Conclusion}

Through Uli pangers Manipulative Game Method can improve student learning outcomes. This can be observed in 
Cycle 1 achievement of student learning outcomes of $74.16 \%$ and 23 learners who have completed in learning. However, the results obtained have not reached expectations, while in cycle 2 achievement of student learning outcomes of $87.09 \%$ From the results of this cycle 2 students have reached the completeness of the class. affiliation (Heading 3): To change the default, adjust the template as follows.

\section{B. Advanced Suggestions}

Based on the results of research, observation, reflection, and data analysis, the researchers provide suggestions for improvement and improvement of learning outcomes:

1. In order to maximize your learning outcomes, use the ladder snake game property that is more attractive to the design so that it is more interesting.

2. Explain in detail the stages of the game so that all students understand the course of the game.
3. The ideal group in the snake ladder game ranges from 4-5 students down menu to differentiate the head from the text.

\section{REFERENCES}

[1] A. Azhar, "MA 2006," Media Pembelajaran.

[2] S. B. Djamarah and A. Zain, "Strategi belajar mengajar," Jakarta: Rineka Cipta, 2006.

[3] S. Tirtonegoro, "Penilaian Hasil Proses Belajar Mengajar," Jakarta: Rineka Cipta, 2001.

[4] R. Susilana, "Riyana, Cepi. 2009," Media Pembelajaran Hakikat, Pengembangan, Pemanfaatan, dan Penilai.

[5] S. Arikunto, Prosedur penelitian: Suatu pendekatan praktik. Rineka Cipta, 1992.

[6] R. Heinich, Instructional media and technologies for learning. Simon \& Schuster Books For Young Readers, 1996. 